\title{
DESAIN EKSPERIMEN EKSTRAKSI DNA BAWANG PUTIH
}

\author{
Elisabeth Ginting', Khalida Syahputri ${ }^{1}$ \\ Departemen Teknik Industri ${ }^{1}$ \\ Universitas Sumatera Utara (USU) \\ Jl. Almamater, Kampus USU Medan 20155 Indonesia \\ Email:ir.elisabethginting@gmail.com \\ Email: syahputrikhalida@gmail.com
}

\begin{abstract}
Abstrak. Desain eksperimen adalah suatu rancangan percobaan yang dilakukan untuk mendapatkan informasi yang berhubungan dengan atau diperlukan untuk persoalan yang sedang diteliti dapat dikumpulkan. Percobaan yang dibuat adalah percobaan ekstraksi DNA bawang putih. Tujuan dari percobaan ini adalah untuk mengetahui berapa banyak takaran garam, sabun, dan kadar alkohol yang efektif agar menghasilkan volume DNA bawang putih yang sebanyak mungkin untuk keperluan medis lanjutan, seperti klonning, untuk menangani kelainan-kelainan genetik dan penemuan obat-obat baru, pada bidang pertanian, peternakan, kehutanan untuk meningkatkan produk-produk baik tanaman maupun hewan unggul maupun di bidang lingkungan dalam hal mengatasi polutan serta perannya dalam kemajuan produksi pangan. Data diperoleh dari percobaan yang dilakukan dengan melihat berapa banyak volume DNA bawang putih yang keluar. DNA bawang putih yang diamati berupa benang-benang putih dan halus yang mengapung ke permukaan cairan. Volume yang didapat merupakan data primer yang akan digunakan untuk pengolahan data keterkaitan antara taraf faktor jumlah garam, jumlah sabun, dan kadar alkohol terhadap volume DNA bawang putih yang dihasilkan. Hasil pengujian kenormalan data dengan uji Anderson Darling maka diperoleh bahwa nilai $p$-value $=0,2540$ sedangkan $\alpha=0,05$ sehingga data yang didapat berdistribusi normal. Dalam pengujian homogenitas varians terhadap jumlah sabun, jumlah garam dan kadar alkohol dapat digunakan uji Bartlet. Pengujian homogenitas varians melalui uji Bartlett, diperoleh bahwa varians untuk interaksi faktor jumlah sabun, jumlah garam, dan kadar alkohol adalah sama. Hasil perhitungan ANAVA menunjukkan untuk setiap perlakuan didapatkan $\mathrm{H}_{\mathrm{o}}$ diterima yang artinya setiap taraf faktor tidak memberikan efek signifikan terhadap perubahan volume DNA bawang putih. Persamaan regresi yang digunakan adalah regresi linear berganda, sehingga diperoleh persamaan regresi $\mathrm{Y}=9,367+(-0,079) \mathrm{X}_{1}+0,975 \mathrm{X}_{2}+0,625 \mathrm{X}_{3}$. Dari perhitungan persamaan regresi didapat untuk hubungan jumlah sabun $\left(X_{1}\right)$, jumlah garam $\left(X_{2}\right)$, dan kadar alkohol $\left(X_{3}\right)$. Koefisien korelasi antara jumlah sabun $\left(X_{1}\right)$ dengan perubahan volume DNA bawang putih (Y) sebesar -0,8679 yang artinya bahwa untuk faktor jumlah sabun memiliki hubungan terbalik terhadap perubahan volume DNA bawang putih. Sebaliknya, koefisien korelasi jumlah garam $\left(\mathrm{X}_{2}\right)$ dan kadar alkohol $\left(\mathrm{X}_{3}\right)$ dengan perubahan volume DNA bawang putih (Y) didapatkan sebesar 0,411 dan 0,2635 yang artinya bahwa untuk faktor jumlah garam memiliki hubungan searah dengan perubahan volume DNA bawang putih.
\end{abstract}

Kata Kunci : Desain Eksperimen, Ekstraksi DNA Bawang Putih, Uji Kenormalan Data, Uji Homogenitas Varians, ANAVA, Regresi, Korelasi, Uji Hipotesis

\section{Pendahuluan}

Desain eksperimen adalah suatu rancangan percobaan (dengan tiap langkah tindakan yang betulbetul terdefinisikan) sedemikian sehingga informasi yang berhubungan dengan atau diperlukan untuk persoalan yang sedang diteliti dapat dikumpulkan. Dengan kata lain, desain sebuah eksperimen merupakan langkah-langkah lengkap yang perlu diambil jauh sebelum eksperimen dilakukan agar supaya data yang semestinya diperlukan dapat diperoleh sehingga akan membawa kepada analisis obyektif dan kesimpulan yang berlaku untuk persoalan yang sedang dibahas.

Percobaan yang dibuat adalah percobaan ekstraksi DNA bawang putih. Tujuan dari percobaan ini adalah untuk mengetahui berapa banyak takaran garam, sabun, dan kadar alkohol yang efektif agar menghasilkan volume DNA bawang putih yang sebanyak mungkin untuk keperluan medis lanjutan, seperti klonning, untuk menangani kelainan-kelainan genetik dan penemuan obat-obat baru, pada bidang pertanian, peternakan, kehutanan untuk meningkatkan produk-produk baik tanaman maupun hewan unggul maupun di bidang lingkungan dalam hal mengatasi polutan serta perannya dalam kemajuan produksi pangan

Biologi Sel dan Molekuler merupakan bidang ilmu yang terus menerus berkembang. Ilmu ini bermanfaat hampir di semua bidang. Baik dalam bidang medis untuk menangani kelainan-kelainan genetik dan penemuan obat-obat baru, pada bidang pertanian, peternakan, kehutanan untuk meningkatkan produk-produk baik tanaman maupun hewan unggul maupun di bidang lingkungan dalam hal mengatasi 
polutan serta perannya dalam kemajuan produksi pangan.

Isolasi DNA merupakan teknik yang penting dalam pengembangan ilmu ini. Derajat kemurnian dan kualitas dalam isolasi DNA sangat mempengaruhi hasil yang akan diperoleh. Secara umum, prosedur ekstraksi yang baik untuk isolasi DNA mencakup tiga hal penting, yaitu harus bisa dihasilkan DNA dengan kemurnian yang tinggi, DNAnya harus utuh, dan jumlahnya mencukupi (konsentrasi tinggi).

Isolasi DNA juga merupakan langkah pertama dalam studi sekuen DNA dari populasi DNA kompleks dan dalam analisis struktur genom dan ekspresi gen. Kuantitas, kualitas dan integritas DNA akan mempengaruhi hasil yang diperoleh secara langsung.

Dengan meningkatnya kebutuhan teknik DNA rekombinan dalam penelitian tumbuhan, metode yang digunakan dalam isolasi DNA menjadi perhatian utama. Metode yang biasa digunakan saat ini merupakan metode yang membutuhkan biaya dan peralatan yang sangat mahal, sehingga di tingkat perguruan tinggi lebih banyak diberikan sebatas teori saja, mahasiswa tidak diberikan pengalaman secara langsung melalui praktikum, hal ini menyebabkan penelitian di bidang ini belum banyak berkembang.

Dengan adanya teknik isolasi DNA yang lebih murah, mudah dan cepat, seorang dosen diharapkan dapat memberikan bekal ketrampilan kepada mahasiswa mengenai suatu teknik dasar yang dapat digunakan untuk mengembangkan sumber daya hayati negara kita yang sangat kaya, agar mahasiswa tersebut dapat mulai berpikir obyektif dan benar dalam mengembangkan teknologi, sehingga penelitian di bidang ini dapat berkembang.

\section{Metode Penelitian}

Penelitian ini bertujuan untuk mengetahui apakah faktor kadar alkohol, jumlah detergen, dan jumlah garam berpengaruh terhadap volume DNA bawang putih yang keluar. Dengan melakukan desain eksperimen faktorial, dapat dianalisa efek dari taraf setiap faktor dan efek interaksi dari taraf faktor yang satu dengan yang lainnya.

Data yang diperoleh adalah hasil pengukuran yang didapat dari percobaan tentang perbedaan volume DNA bawang putih yang keluar setelah bawang dicampur dengan alkohol, garam, dan sabun. Selanjutnya diolah dengan uji kenormalan data yaitu uji kenormalan secara manual dan uji kenormalan dengan Minitab, lalu uji homogenitas varians yaitu uji homogenitas varians untuk setiap faktor dan untuk interaksi faktor, perhitungan ANAVA secara manual dengan metode Yates $\left(2^{3}\right)$ dan dengan menggunakan software SPSS, uji rata-rata sesudah ANAVA yaitu uji sesudah ANAVA untuk interaksi semua faktor dengan menggunakan uji Tukey HSD, dilakukan juga perhitungan persamaan \& kelinearan regresi secara manual ataupun dengan software SPSS, selain itu juga dilakukan penghitungan koefisien korelasi baik dengan cara manual maupun dengan menggunakan software SPSS dan koefiensi determinansinya. Terakhir dilakukan pengujian hipotesis korelasi.

\subsection{Metode Percobaan}

Rancangan faktorial yang digunakan adalah rancangan faktorial $2 \times 2 \times 2$ atau rancangan faktorial $2^{3}$. Adapun faktor-faktor yang digunakan dalam menentukan volume DNA bawang putih adalah faktor-faktor yang dianggap berpengaruh terhadap proses ekstraksi DNA bawang putih. Faktorfaktornya adalah alcohol (70\% dan 96\%), garam (1 sdm dan $2 \mathrm{sdm}$ ) dan sabun (1 sdm dan $2 \mathrm{sdm}$ ).

Langkah kerja pada percobaan ini, yaitu:

1. Disiapkan semua alat dan bahan.

2. Ditimbang bawang putih sebanyak 25 gram dan dicincang halus

3. Dicampur bawang putih dengan air, garam, dan sabun kedalam gelas kemudian aduk hingga rata.

4. Dipanaskan gelas yang berisi campuran bawang putih ke dalam panci berisi air sesuai waktu yang ditetapkan.

5. Diletakkan gelas ke dalam air es sesuai waktu yang ditetapkan.

6. Disaring air campuran bawang putih ke dalam gelas ukur.

7. Dituangkan alkohol dingin sebanyak $60 \mathrm{ml}$

8. Dihitung volume DNA bawang putih yang tampak.

3. Hasil dan Pembahasan

Berikut ini tampilan dari hasil pengukuran volume DNA bawang putih.

Tabel 3.1. Hasil Pengukuran Volume DNA Bawang Putih(ml)

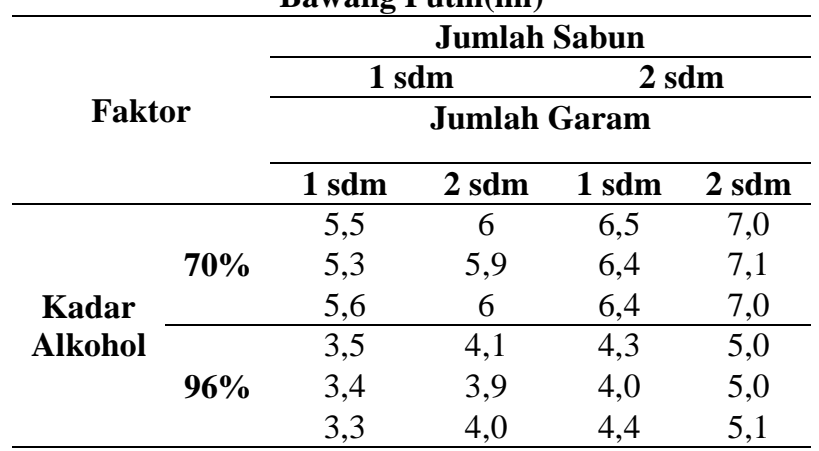

\subsection{Uji Kenormalan Data}

Uji kenormalan data yang diperoleh dilakukan dengan menggunakan Anderson Darling Test. Tahapan pengujian kenormalan data menggunakan Anderson Darling Test adalah sebagai berikut:

1. Data pengamatan diurutkan mulai dari pengamatan dengan nilai terkecil sampai nilai terbesar. 
2. Dihitung nilai $\mathrm{Z}$ dengan menggunakan rumus berikut ini:

$$
(Z)=\frac{X-\bar{X}}{\sigma}=\frac{3,3-5,1958}{1,2114}=-1,5651
$$

3. Tentukan nilai dari AD:

$$
A D=-N-\frac{2 i-1}{N}\left(\ln \left(F\left(Z_{i}\right)\right)+\ln \left(1-F\left(Z_{N+1-i}\right)\right)\right)
$$

4. Hitung nilai $\mathrm{AD}^{*}$ :

$$
\mathrm{AD}^{*}=0,3952\left(1+\frac{0,75}{24}+\frac{2,25}{24^{2}}\right)=0,4091
$$

5. Hitung nilai dari $p$-value

$$
\begin{aligned}
p \text {-value } & =\exp \left(0,9177-4,279\left(\mathrm{AD}^{*}\right)-1,38\left(\mathrm{AD}^{*}\right)^{2}\right. \\
& =0,3540
\end{aligned}
$$

6. Kriteria pengambilan keputusannya adalah: Ho : Data tersebut tidak berdistribusi Normal H1 : Data tersebut berdistribusi Normal Jika $p$-value $>\alpha$, maka Ho ditolak Jika $p$-value $\leq \alpha$, maka Ho diterima

Bandingkan antara nilai $p$-value dengan $\alpha, p$ value $>\alpha(0,3540>0,05)$. Kesimpulannya, Ho ditolak yang berarti data berdistribusi normal.

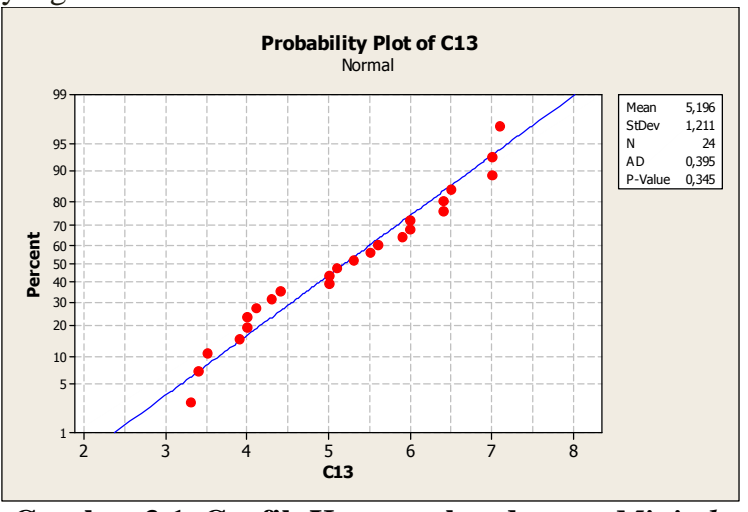

Gambar 3.1. Grafik Kenormalan dengan Minitab

\subsection{Uji Homogenitas Varians}

Uji homogenitas ini dilakukan dengan menggunakan uji Bartlett. Uji ini digunakan untuk membuktikan kesamaan variansi untuk beberapa taraf faktor untuk suatu faktor.

Uji Bartlett dilakukan dengan langkahlangkah sebagai berikut:

1. Menentukan hipotesis.

Ho: $\mathrm{S}_{1}{ }^{2}=\mathrm{S}_{2}{ }^{2}=\mathrm{S}_{3}{ }^{2}=\mathrm{S}_{\mathrm{n}}{ }^{2}$

Hi : Tidak semua variansi sama

2. Menentukan nilai $\alpha$

3. Menentukan Daerah Kritis

Daerah Kritis : $b_{\text {hitung }}>b_{k}(0,05 ; n)$

4. Perhitungan :

$$
\begin{gathered}
s_{p}{ }^{2}=\frac{\sum_{i=1}^{i}\left(n_{i}-1\right) s_{i}{ }^{2}}{N-k} \\
b=\frac{\left[\left(s_{1}{ }^{2}\right)^{n_{1-1}}\left(s_{2}\right)^{\left.n_{2-1} \ldots\left(s_{i}{ }^{2}\right)^{n_{i-1}}\right]^{\frac{1}{N-k}}}\right.}{s_{p}{ }^{2}}
\end{gathered}
$$

5. Kesimpulan: Ho diterima jika $b_{\text {hitung }}>b_{k}(0.05 ; n)$ Hasil uji Bartlett, yaitu;

1. Uji Bartlett untuk Faktor Alkohol $\mathrm{b}_{\text {hitung }}>\mathrm{b}_{2}(0.05 ; 12) .0,9998>0,8332$ maka Ho diterima. Variansi kedua taraf faktor alkohol sama

2. Uji Bartlett untuk Faktor Jumlah Sabun $b_{\text {hitung }}>b_{2}(0,05 ; 12)(0,9883>0,8332)$ maka Ho diterima. Variansi kedua taraf faktor jumlah sabun sama

3. Uji Bartlett untuk Faktor Jumlah Garam $\mathrm{b}_{\text {hitung }}>\mathrm{b}_{2}(0,05 ; 12)(0,9994>0,8332)$ maka Ho diterima. Semua variansi kedua taraf faktor jumlah garam sama

4. Uji Bartlett untuk Interaksi Faktor $b_{\text {hitung }}>b_{3}(0,05 ; 3),(3,1966>0.520)$ maka Ho diterima. Semua variansi untuk interaksi ketiga taraf faktor adalah sama.

\subsection{Perhitungan ANAVA}

Jenis eksperimen pada percobaan mengukur volume DNA bawang putih yaitu faktor jumlah sabun, jumlah garam dan alkohol yang masingmasing terdiri dari 2 taraf. Eksperimen dilakukan dengan menggunakan model acak axbxc.

Perhitungan ANAVA dengan model acak dilakukan untuk melihat apakah perlakuanperlakuan yang diberikan pada perbandingan yang berpengaruh secara signifikan terhadap hasil yang didapat.

Syarat:

$\mathrm{H}_{\mathrm{o}}$ :Faktor yang diberikan tidak mempengaruhi volume DNA bawang putih secara signifikan.

\begin{tabular}{|c|c|c|c|c|c|c|c|}
\hline \multicolumn{2}{|c|}{$\begin{array}{c}\text { Sumber } \\
\text { Variasi }\end{array}$} & Dk & JK & KT & $\begin{array}{c}\text { F } \\
\text { hitung }\end{array}$ & $\begin{array}{c}F \\
\text { tabel }\end{array}$ & Keterangan \\
\hline \multicolumn{2}{|c|}{ Rata-rata } & 1 & 647,9204 & 647,9204 & - & - & - \\
\hline \multirow{7}{*}{ 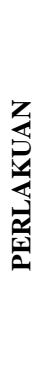 } & $\mathbf{A}$ & 1 & 5,7037 & 5,7037 & - & - & \multirow{3}{*}{$\begin{array}{c}\text { Tidak ada } \\
\text { uji eksak } \\
\text { yang dapat } \\
\text { digunakan }\end{array}$} \\
\hline & B & 1 & 2,3437 & 2,3437 & - & - & \\
\hline & C & 1 & 25,4204 & 25,4204 & - & - & \\
\hline & $\mathbf{A B}$ & 1 & 0,0338 & 0,0338 & 9,0000 & 161 & H0 diterima \\
\hline & $\mathbf{A C}$ & 1 & 0,0104 & 0,0104 & 2,7778 & 161 & H0 diterima \\
\hline & BC & 1 & 0,0338 & 0,0338 & 9,0000 & 161 & H0 diterima \\
\hline & $\mathbf{A B C}$ & 1 & 0,0037 & 0,0037 & 0,3000 & 161 & H0 diterima \\
\hline \multicolumn{2}{|c|}{ Kekeliruan } & 16 & 0,2000 & 0,0125 & & - & - \\
\hline \multicolumn{2}{|c|}{ Jumlah } & 24 & 681,6700 & 681,6700 & - & - & - \\
\hline
\end{tabular}

$\mathrm{H}_{1}$ : Faktor yang diberikan mempengaruhi volume DNA bawang putih secara signifikan.

Jika $\mathrm{F}$ hitung $<\mathrm{F}$ tabel, maka $\mathrm{H}_{\mathrm{o}}$ diterima.

Jika $\mathrm{F}$ hitung $>\mathrm{F}$ tabel, maka $\mathrm{H}_{\mathrm{o}}$ ditolak

Tabel 3.2. Tabel ANAVA untuk Eksperimen Faktorial $2^{3}$ Model Acak 
Keterangan:

A = faktor jumlah sabun

$\mathrm{B}=$ faktor jumlah garam

$\mathrm{C}=$ faktor alkohol

$\mathrm{AB}=$ interaksi faktor jumlah sabun dan jumlah garam

$\mathrm{AC}=$ interaksi faktor jumlah sabun dan alkohol

$\mathrm{BC}=$ interaksi faktor jumlah garam dan alkohol

$\mathrm{ABC}=$ interaksi faktor jumlah sabun, jumlah garam dan alkohol

\subsection{Uji Persamaan Regresi}

Dari data yang diperoleh dapat dibuat suatu persamaan regresi. Adapun persamaan yang akan digunakan dalam perhitungan persamaan regresi adalah sebagai berikut.

1. $\sum Y=a n+b \sum x_{1}+c \sum x_{2}+d \sum x_{3}$

$124,7=24 a+1992 b+36 c+36 d$

2. $\sum Y x_{1}=a \sum x_{1}+b \sum x_{1}{ }^{2}+c \sum x_{1} x_{2}+d \sum x_{1} x_{3}$

$10029=1992 \mathrm{a}+169392 \mathrm{~b}+2988 \mathrm{c}+2988 \mathrm{~d}$

3. $\sum Y x_{2}=a \sum x_{2}+b \sum x_{2} x_{1}+c \sum x_{2}{ }^{2}+d \sum x_{2} x_{3}$

$192,9=36 a+2988 b+60 c+54 d$

4. $\sum Y x_{3}=a \sum x_{3}+b \sum x_{3} x_{1}+c \sum x_{3} x_{2}+d \sum x_{3}{ }^{2}$

$190,8=36 \mathrm{a}+2988 \mathrm{~b}+54 \mathrm{c}+60 \mathrm{~d}$

Dari persamaan regresi di atas maka dapat dinyatakan dalam bentuk matriks sebagai berikut.

$\left(\begin{array}{rrrr|r}24 & 1992 & 36 & 36 & 124,7 \\ 1992 & 169392 & 2988 & 2988 & 10029 \\ 36 & 2988 & 60 & 54 & 192,9 \\ 36 & 2988 & 54 & 60 & 190,8\end{array}\right)$

Untuk mendapatkan nilai-nilai a, b, c, dan d, maka dilakukan eliminasi matriks dengan metode Gauss-Jordan.

$\left(\begin{array}{rrrr|r}1,0000 & 0,0000 & 0,0000 & 0,0000 & 9,367 \\ 0,0000 & 1,0000 & 0,0000 & 0,0000 & -0,079 \\ 0,0000 & 0,0000 & 1,0000 & 0,0000 & 0,975 \\ 0,0000 & 0,0000 & 0,0000 & 1,0000 & 0,625\end{array}\right)$

$\mathrm{a}=9,367$

Dari perhitungan di atas akan diperoleh:

$\mathrm{b}=-0,079$

$\mathrm{c}=0,975$

$\mathrm{d}=0,625$

Dari nilai-nilai tersebut, diperoleh hasil perhitungan persamaan regresi untuk pengukuran volume DNA adalah sebagai berikut.

$$
\mathrm{Y}=9,367+(-0,079) \mathrm{X}_{1}+0,975 \mathrm{X}_{2}+0,625 \mathrm{X}_{3}
$$

Dari perhitungan persamaan regresi didapat untuk hubungan jumlah $\operatorname{sabun}\left(\mathrm{X}_{1}\right)$, jumlah garam $\left(\mathrm{X}_{2}\right)$, dan kadar alkohol $\left(\mathrm{X}_{3}\right)$

\subsection{Pengujian Kelinearan Regresi}

Uji kelinearan regresi dilakukan untuk mengetahui apakah garis regresi yang diperoleh linear atau tidak linear. Adapun langkah-langkah yang dilakukan pada pengujian kelinearan regresi adalah sebagai berikut.

1. Penentuan hipotesis

$\mathrm{H}_{0}$ : garis regresi tidak linear

$\mathrm{H}_{\mathrm{i}}$ : garis regresi linear

Apabila $F_{\text {Hitung }}$ berada di dalam wilayah kritik, maka Ho ditolak yang berarti $\mathrm{Hi}$ diterima sedangkan apabila $\mathrm{F}_{\text {Hitung }}$ berada di luar wilayah kritik, maka Ho diterima.

2. Penentuan wilayah kritik

Dengan taraf nyata sebesar 0,05, diperoleh $\mathrm{F}_{0,05(3,23)}$ sebesar 3,028 dengan interpolasi yang menyebabkan wilayah kritik $F>3,028$.

3. Penentuan $\mathrm{F}_{\text {Hitung }}$

Penentuan $\mathrm{F}_{\text {Hitung }}$ dapat dilakukan dengan menggunakan perhitungan ANAVA.

a. Jumlah Kuadrat Regresi (JKR)

$$
J K R=\sum(\hat{y}-\bar{y})^{2}=33,3658
$$

b. Jumlah Kuadrat Error (JKE)

$$
J K E=\sum(Y-\hat{y})^{2}=0,2866
$$

c. Jumlah Kuadrat Total (JKT)

$$
J K T=\Sigma(Y-\bar{y})^{2}=33,7496
$$

Nilai Degree of freedom (Df) regression adalah 3 disebabkan $\mathrm{v}=\mathrm{n}-1$, dimana $\mathrm{n}$ adalah 4 koefisien pada persamaan regresi yaitu a, b, c, dan d. sedangkan untuk Df residual bernilai 23 karena selisih antara Df total dengan Df regression, dimana Df total = banyaknya percobaan dikurang satu.

Setelah diperoleh nilai-nilai di atas, selanjutnya ditentukan nilai $\mathrm{F}_{\text {Hitung }}$ yang dapat dilihat pada Tabel 5.20 .

Tabel 5.20. Penentuan $F_{\text {Hitung }}$

\begin{tabular}{cccccc}
\hline $\begin{array}{c}\text { Sumber } \\
\text { Variasi }\end{array}$ & JK & Df & KT & $\begin{array}{c}\text { F } \\
\text { Hitung }\end{array}$ & $\begin{array}{c}\text { F } \\
\text { Tabel }\end{array}$ \\
\hline Regression & 33,3658 & 3,0000 & 11,1219 & 776,1406 & 3,0280 \\
Residual & 0,2866 & 20,0000 & 0,0143 & - & - \\
\hline Total & 33,7496 & 23,0000 & 11,1363 & - & - \\
\hline
\end{tabular}

\subsection{Perhitungan Fungsi Koefisien Korelasi}

$$
r=\frac{n \sum_{i=1}^{n} X i Y i-\left(\sum_{i=1}^{n} X i\right)\left(\sum_{i=1}^{n} Y i\right)}{\sqrt{\left[n \sum_{i=1}^{n} X i^{2}-\left(\sum_{i=1}^{n} X i\right)^{2}\right]\left[n \sum_{i=1}^{n} Y i^{2}-\left(\sum_{i=1}^{n} Y i\right)^{2}\right]}}
$$

Perhitungan korelasi dilakukan dengan menggunakan perhitungan korelasi tunggal untuk melihat hubungan antara faktor Jumlah Sabun, 
Jumlah Garam dan Kadar Alkohol dengan perubahan Volume DNA bawang.

1. Perhitungan Koefisien Korelasi Jumlah Sabun Terhadap Perubahan Volume DNA

$$
r=-0,8679 \text {. }
$$

Hasil perhitungan korelasi ini menyatakan bahwa untuk faktor Jumlah Sabun memiliki hubungan terbalik terhadap perubahan volume DNA. Artinya jika nilai variabel Jumlah Sabun besar maka nilai variabel perubahan volume DNA menjadi rendah.

2. Perhitungan Koefisien Korelasi Jumlah Garam Terhadap Perubahan Volume DNA

$$
r=0,411 \text {. }
$$

Hasil perhitungan korelasi ini menyatakan bahwa untuk faktor Jumlah Garam memiliki hubungan searah terhadap Volume DNA. Artinya jika nilai variabel Jumlah Garam semakin besar maka nilai variabel perubahan Volume DNA semakin tinggi.

3. Perhitungan Koefisien Korelasi Kadar Alkohol Terhadap Perubahan Volume DNA

$$
\mathrm{r}=0,2635
$$

Hasil perhitungan korelasi ini menyatakan bahwa untuk faktor kadar alkohol memiliki hubungan searah. Artinya jika nilai variabel kadar alkoholbesar, maka nilai variabel perubahan Volume DNA semakin tinggi.

\subsection{Perhitungan Korelasi Berganda}

Korelasi berganda merupakan korelasi dari beberapa variabel bebas (X) secara serentak dengan variabel terikat (Y) dengan menggunakan persamaan berikut :

$$
\begin{gathered}
r_{y_{x_{1}, x_{2}, x_{3}}}=\sqrt{\frac{a_{1} \sum x_{1} y+a_{2} \sum x_{2} y+a_{3} \sum x_{3} y}{\sum y^{2}}} \\
r_{y_{x_{1}, x_{2}, x_{3}}}=0,844
\end{gathered}
$$

Pada perhitungan koefisien korelasi berganda diperoleh nilai $r=0,844$. Hasil perhitungan korelasi berganda ini menyatakan bahwa untuk faktor-faktor memiliki hubungan searah dengan korelasi sangat kuat terhadap perubahan Volume DNA karena nilai $r>0$.

\subsection{Perhitungan Hipotesis Korelasi}

Langkah-langkah pengujian hipotesis:

1. Penetapan hipotesis

$\mathrm{H}_{0}$ : Koefisien korelasi tidak signifikan

$\mathrm{H}_{1}$ : Koefisien korelasi signifikan

2. Penetapan wilayah kritik

Wilayah kritik $t_{\text {hitung }}>t_{\alpha / 2}$. dan $-t_{\text {hitung }}<t_{\alpha / 2}$

Wilayah kritik $\mathrm{t}_{\text {hitung }}>\mathrm{t}_{0.025}$ dan - $\mathrm{t}_{\text {hitung }}<\mathrm{t}_{0.025}$

Wilayah kritik $t_{\text {hitung }}>2,069$ dan $-t_{\text {hitung }}<-2,069$

3. Menghitung nilai $t_{\text {hitung }}$

$$
t=\frac{\sqrt{n-3}}{2} \ln \left(\frac{1+r}{1-r}\right)
$$

Hasil pengujian hipotesis korelasi pada tiap taraf faktor adalah sebagai berikut:

1. Pengujian Hipotesis Korelasi Faktor Jumlah Sabun

$$
t=\frac{\sqrt{24-3}}{2} \ln \left(\frac{1+(-0,8679)}{1-(-0,8679)}\right)=-6,0691
$$

Wilayah kritik $t_{\text {hitung }}<2,069$ dan $-t_{\text {hitung }}>-2,069$. $\mathrm{H}_{0}$ ditolak yang artinya koefisien korelasi signifikan.

2. Pengujian Hipotesis Korelasi Faktor Jumlah Garam

$$
t=\frac{\sqrt{24-3}}{2} \ln \left(\frac{1+(0,4111)}{1-(0,4111)}\right)=2,0022
$$

Wilayah kritik $t_{\text {hitung }}>2,069$ dan $-t_{\text {hitung }}>-2,069$. $\mathrm{H}_{0}$ diterima yang artinya koefisien korelasi tidak signifikan.

3. Pengujian Hipotesis Korelasi Faktor Kadar Alkohol

$$
t=\frac{\sqrt{24-3}}{2} \ln \left(\frac{1+(0,2635)}{1-(0,2635)}\right)=-1,2638
$$

Wilayah kritik $t_{\text {hitung }}>2,069$ dan $-t_{\text {hitung }}>-2,069$. $\mathrm{H}_{0}$ diterima yang artinya koefisien korelasi tidak signifikan.

\section{Kesimpulan}

Kesimpulan yang dapat diambil dari penelitian pada pengukuran volume DNA bawang putih adalah:

1. Data yang dikumpulkan pada desain eksperimen berdasarkan faktor-faktor yang mempengaruhi perubahan volume DNA bawang putih berdistribusi normal sesuai dengan hasil pengujian kenormalan data dengan uji Anderson Darling.

2. Dari hasil uji keseragaman data yang menggunakan uji Bartlet didapatkan bahwa semua data faktor jumlah sabun, jumlah garam, kadar alcohol dan interaksi antara ketiga faktor adalah seragam.

3. Dari data pengukuran volume DNA, diperoleh persamaan regresinya adalah

$\mathrm{Y}=9,367+(-0,079) \mathrm{X}_{1}+0,975 \mathrm{X}_{2}+0,625 \mathrm{X}_{3}$, sehingga dapat diramalkan volume DNA bawang putih dengan taraf faktor tertentu.

4. Pada perhitungan koefisien korelasi diperoleh bahwa jumlah sabun memiliki hubungan yang terbalik dengan jumlah garam dan kadar alkohol yang memiliki hubungan searah dengan perubahan volume DNA bawang putih.

5. Dari hasil perhitungan ANAVA didapatkan bahwa faktor jumlah sabun, jumlah garam, kadar alcohol dan interaksi antara ketiga faktor tidak 
terdapat efek faktor-faktor karena $\mathrm{H}_{\mathrm{o}}$ untuk setiap perlakuan diterima.

\section{DAFTAR PUSTAKA}

Sudjana. 1994. Desain dan Analisis Eksperimen. Surabaya: ITS

Walpole, Ronald E. 1995. Pengantar Statistik Edisi Ketiga. Jakarta: PT. Gramedia Pustaka Utama Montgomery, Doughlas C. 1991. Design and Analysis of Experiment. Third Edition. New York:John Wiley \& Sons,. 